\title{
Microarray analysis of cytoplasmic versus whole cell RNA reveals a considerable number of missed and false positive mRNAs
}

\author{
HEIDI W. TRASK, ${ }^{1}$ RICHARD COWPER-SAL-LARI, ${ }^{1,2}$ MAUREEN A. SARTOR, ${ }^{3,7}$ JIANG GUI, ${ }^{1,4}$ \\ CATHERINE V. HEATH, ${ }^{1}$ JANHAVI RENUKA, ${ }^{1}$ AZARA-JANE HIGGINS, ${ }^{5}$ PETER ANDREWS, ${ }^{1,2}$ \\ MURRAY KORC, ${ }^{1,4,6}$ JASON H. MOORE, ${ }^{1,2}$ and CRAIG R. TOMLINSON ${ }^{1,4,6}$ \\ ${ }^{1}$ Norris Cotton Cancer Center, Dartmouth Hitchcock Medical Center, Lebanon, New Hampshire 03756, USA \\ ${ }^{2}$ Department of Genetics, Dartmouth Hitchcock Medical Center, Lebanon, New Hampshire 03756, USA \\ ${ }^{3}$ Department of Environmental Health, University of Cincinnati, Cincinnati, Ohio 45267, USA \\ ${ }^{4}$ Department of Medicine, Dartmouth Hitchcock Medical Center, Lebanon, New Hampshire 03756, USA \\ ${ }^{5}$ Department of Biology and Biochemistry, University of Bath, Bath, BA2 7AY, United Kingdom \\ ${ }^{6}$ Department of Pharmacology and Toxicology, Dartmouth Hitchcock Medical Center, Lebanon, New Hampshire 03756, USA
}

\begin{abstract}
With no known exceptions, every published microarray study to determine differential mRNA levels in eukaryotes used RNA extracted from whole cells. It is assumed that the use of whole cell RNA in microarray gene expression analysis provides a legitimate profile of steady-state mRNA. Standard labeling methods and the prevailing dogma that mRNA resides almost exclusively in the cytoplasm has led to the long-standing belief that the nuclear RNA contribution is negligible. We report that unadulterated cytoplasmic RNA uncovers differentially expressed mRNAs that otherwise would not have been detected when using whole cell RNA and that the inclusion of nuclear RNA has a large impact on whole cell gene expression microarray results by distorting the mRNA profile to the extent that a substantial number of false positives are generated. We conclude that to produce a valid profile of the steady-state mRNA population, the nuclear component must be excluded, and to arrive at a more realistic view of a cell's gene expression profile, the nuclear and cytoplasmic RNA fractions should be analyzed separately.
\end{abstract}

Keywords: dioxin; genomics; nuclear RNA; pancreatic cancer; steady-state mRNA

\section{INTRODUCTION}

Levels of steady-state mRNA, which is that population of mature processed RNA in eukaryotes competent for translation into proteins, are maintained in the cytoplasm by the ongoing and competing rates of mRNA synthesis and turnover (Garcia-Martinez et al. 2004). Conventional gene expression microarrays are thought to be the examination of global steady-state mRNA levels within the total RNA population (Brown and Botstein 1999), in which whole cell RNA is isolated, converted in vitro to a labeled cDNA

${ }^{7}$ Present address: Center for Computational Medicine and Biology, University of Michigan, 2017 Palmer Commons, 100 Washtenaw Avenue, Ann Arbor, MI 48109-2218, USA.

Reprint requests to: Craig R. Tomlinson, Department of Medicine, Dartmouth Hitchcock Medical Center, One Medical Center Drive, Lebanon, NH 03756, USA; e-mail: Craig.R.Tomlinson@Dartmouth.edu; fax: 603-653-9952.

Article published online ahead of print. Article and publication date are at http://www.rnajournal.org/cgi/doi/10.1261/rna.1677409. or cRNA, and hybridized to arrayed DNA probes representing a set of genes (Brown and Botstein 1999). The belief that steady-state cytoplasmic mRNA levels are accurately assessed within the sphere of total RNA from whole cell preparations is based on two assumptions. First, with the exception of replication-dependent histone mRNAs (Birnstiel et al. 1985; Dominski and Marzluff 2007) and other possible nonpolyadenylated mRNAs (Cheng et al. 2005), all eukaryotic mRNA species uniquely possess $3^{\prime}$ polyadenylated tails; and in the standard in vitro labeling reaction with oligo(dT) as the primer, only $3^{\prime}$ polyadenylated mRNA will be labeled (Van Ness and Hahn 1980). Second, because most 3' polyadenylated RNA resides in the cytoplasm (Jackson et al. 2000), the nuclear RNA contribution from the whole cell preparation is negligible (Cheadle et al. 2005).

In a previous study to determine the effects of the pervasive environmental toxicant 2,3,7,8-tetrachlorodibenzo-p-dioxin (TCDD, or dioxin) on nuclear RNA levels 
Vehicle-Treated Mouse 1c1c7 Cells

A
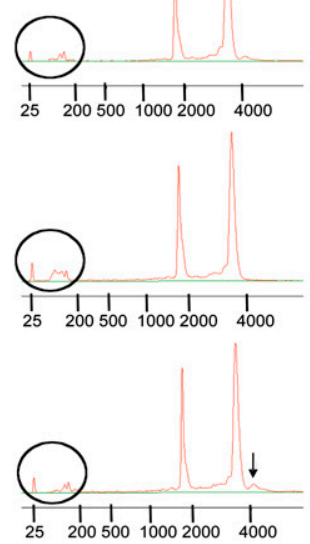

Sham-Vector Human BxPC3 Cells

C
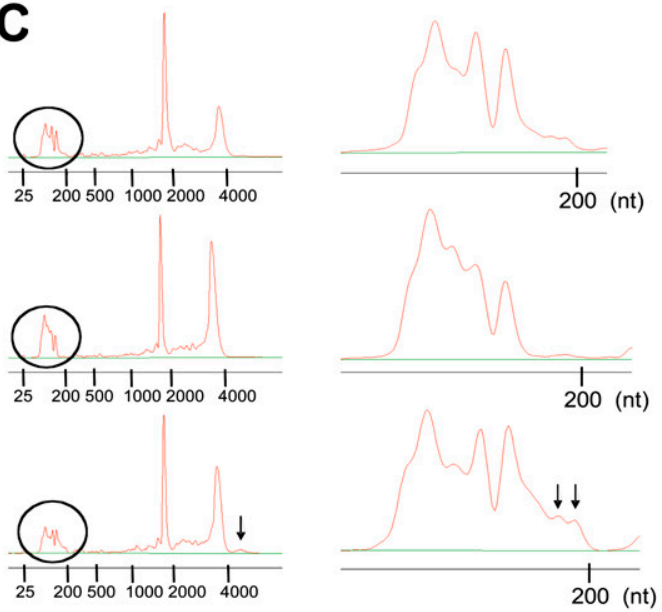

Whole-cell RNA
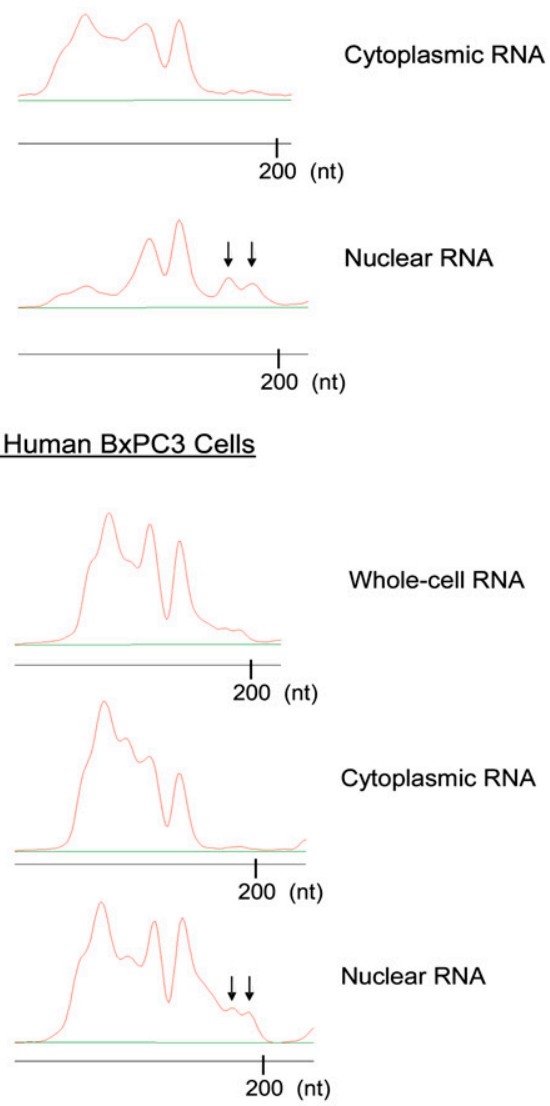

Cytoplasmic RNA
TCDD-Treated Mouse 1c1c7 Cells
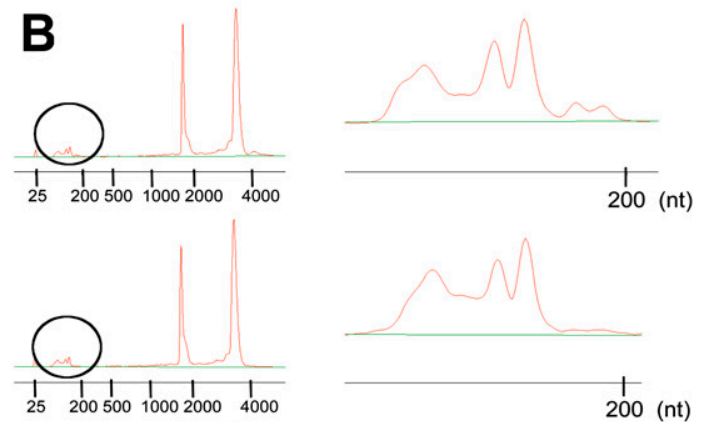

$\downarrow \downarrow$
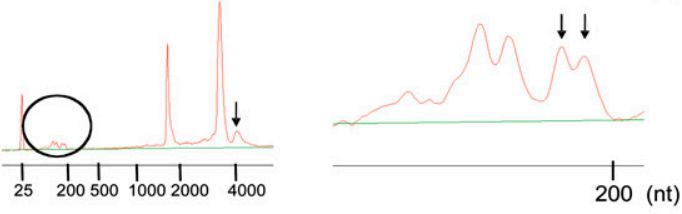

Smad 4-Positive Human BxPC3 Cells

D
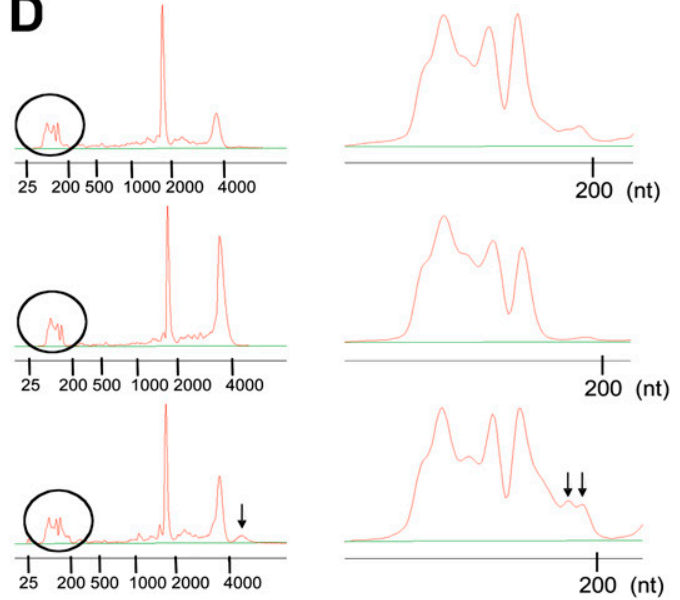

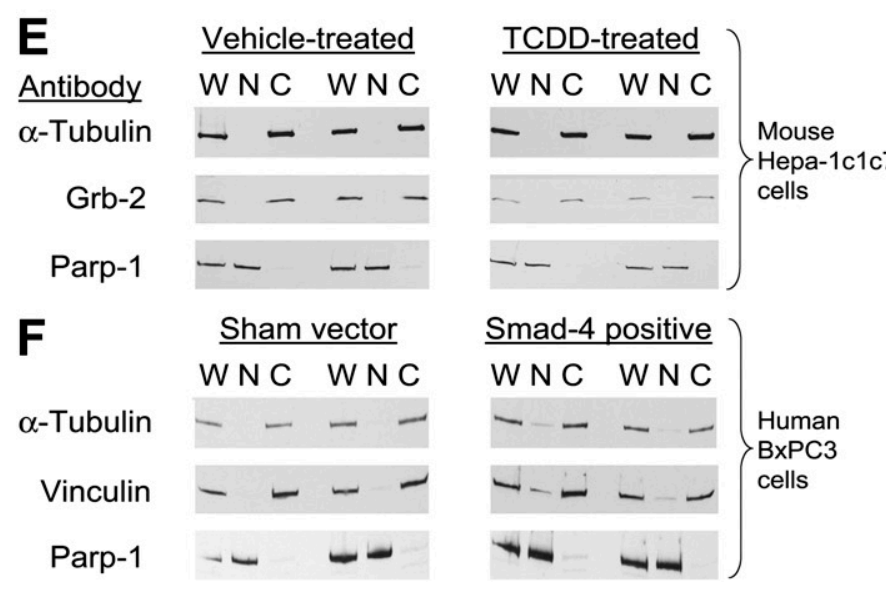

FIGURE 1. (Legend on next page) 
in mouse embryonic fibroblasts, we observed that the nuclear RNA compartment produced a substantially different RNA gene expression profile than that of the cytoplasmic compartment when using the same labeling methods (Schwanekamp et al. 2006). These findings suggested that whole cell RNA did not accurately represent steady-state mRNA levels. As a result, we decided to test the hypothesis that the nuclear RNA component was not a negligible contributor to whole cell gene expression microarrays and that whole cell RNA may be a misleading representation of cytoplasmic steady-state mRNA levels.

\section{RESULTS}

To test our hypothesis, we carried out our study based on the premise that if whole cell RNA accurately represented cytoplasmic steady-state mRNA levels, then the RNA profiles from the whole cell and cytoplasmic compartments would be similar and the RNA from the nuclear compartment would label and hybridize relatively weakly; i.e., the nuclear RNA contribution would be negligible. To rigorously test the hypothesis, two criteria would have to be met. First, the nuclear and cytoplasmic fractions must have little crosscontamination; and to determine the degree of crosscontamination, the relative proportions of the nuclear and cytoplasmic fractions must mirror the respective proportions of the nuclear and cytoplasmic compartments of the whole cell. Second, the microarray methods and data analysis for the whole cell, cytoplasmic, and nuclear fractions must be carried out identically using conventional methods.

Nuclear and cytoplasmic fractions were purified from mouse Hepa-1clc7 (Hankinson et al. 1991) and human BxPC3 cells (Yasutome et al. 2005), from which total RNA (Schwanekamp et al. 2006) and proteins (Yasutome et al. 2005) were isolated from the same fractions using TRI reagent (Molecular Research Center). Two approaches were taken to demonstrate that the first criterion was satisfied, in which clean nuclear and cytoplasmic fractions were isolated (Fig. 1). First, nuclear and cytoplasmic total RNA preparations have distinct $260-\mathrm{nm}$ absorbance profiles (Wang et al. 2006). We observed that the nuclear RNA profiles always had three unique peaks (Fig. 1A-D, marked by arrows), which were not observed in any of the cytoplasmic RNA profiles and were intermediate in all of the whole cell RNA profiles, indicating little cross-contamination between the nuclear and cytoplasmic fractions. Second, proteins from the whole cell, nuclear, and cytoplasmic fractions were resolved by gel electrophoresis and blotted for Western analysis (Fig. 1E,F). Antibodies specific to proteins found in the nucleus (PARP-1) or cytoplasm ( $\alpha$-tubulin and GRB-2 in mouse; $\alpha$-tubulin and vinculin in human) produced bands in the expected lanes; and a given band in the nuclear or cytoplasmic fraction was nearly the same intensity as that in the whole cell, again indicating little cross-contamination between the nuclear and cytoplasmic fractions. In order for the whole cell, nuclear, and cytoplasmic samples to be examined in the proper proportions, (1) equal numbers of cells were used in the whole cell and nuclear/cytoplasmic preparations, and (2) the final protein and RNA samples for the whole cell, nuclear, and cytoplasmic fractions were suspended in equal volumes; and, in turn, equal volumes of each fraction were used in all subsequent analyses to maintain relative proportions among the whole cell, nuclear, and cytoplasmic fractions.

The second criterion was met by carrying out the same microarray procedures and analyses for all the cellular fractions using conventional methods. Two diverse cell lines and experimental conditions were selected in order to more broadly test our hypothesis. The first set of experiments was a comparison of vehicle-treated and TCDDtreated mouse Hepa-1clc7 hepatocyte cells (Hankinson et al. 1991), and the second experimental set compared the relative RNA levels of sham vector $\left(S M A D 4^{-1-}\right)$ and SMAD4-positive (Yasutome et al. 2005) human BxPC3 pancreatic cancer cell lines (Tan et al. 1986). The microarray results for selected genes were confirmed by quantitative real-time polymerase chain reaction assays using SYBR green and designed primers (Supplemental Tables S1, S2; Guo et al. 2004).

Microarray analyses were carried out by identifying significantly changed $(P$-value $\leq 0.05)$ RNA levels between the control whole cell, nuclear, and cytoplasmic fractions and the corresponding experimental whole cell, nuclear, and cytoplasmic fractions from the Hepa-1c1c7 and BxPC3 cells (Fig. 2A). Each set of microarray experiments was carried out with four biological replicates using equal amounts of RNA ( $2 \mu \mathrm{g}$ of total RNA) on Agilent mouse and human $4 \times 44$ microarrays (Schwanekamp et al. 2006).

The disparity between whole cell and cytoplasmic RNA populations is shown in heat maps (Supplemental Fig. S1) that display the greatest differentially expressed genes in the

FIGURE 1. Isolation of the nuclear and cytoplasmic cellular fractions. Equal amounts $(0.1 \mu \mathrm{g})$ of total RNA from the whole cell, cytoplasmic, and nuclear fractions were analyzed using an Agilent Bioanalyzer 2100. The $\mathrm{A}_{260}$ tracings of the total RNA are shown on the left for vehicle-treated $(A)$ and TCDD-treated $(B)$ mouse Hepa-1c1c7 cells and for sham-vector $\left(S M A D 4^{-l-}\right)(C)$ and SMAD4-positive $(D)$ human BxPC3 cells. The circled area on each tracing was blown up and shown on the right. (Arrows) Peaks representing processed nuclear RNA byproducts that distinguish the nuclear from the cytoplasmic RNAs. Proteins were also isolated from two sets of the whole cell, cytoplasmic, and nuclear fractions from mouse Hepa-1c1c7 $(E)$ and human BxPC3 $(F)$ cells, resolved by polyacrylamide gel electrophoresis, and transferred by electrophoresis for Western analysis. (W) Whole cell, (N) nucleus, (C) cytoplasm. 

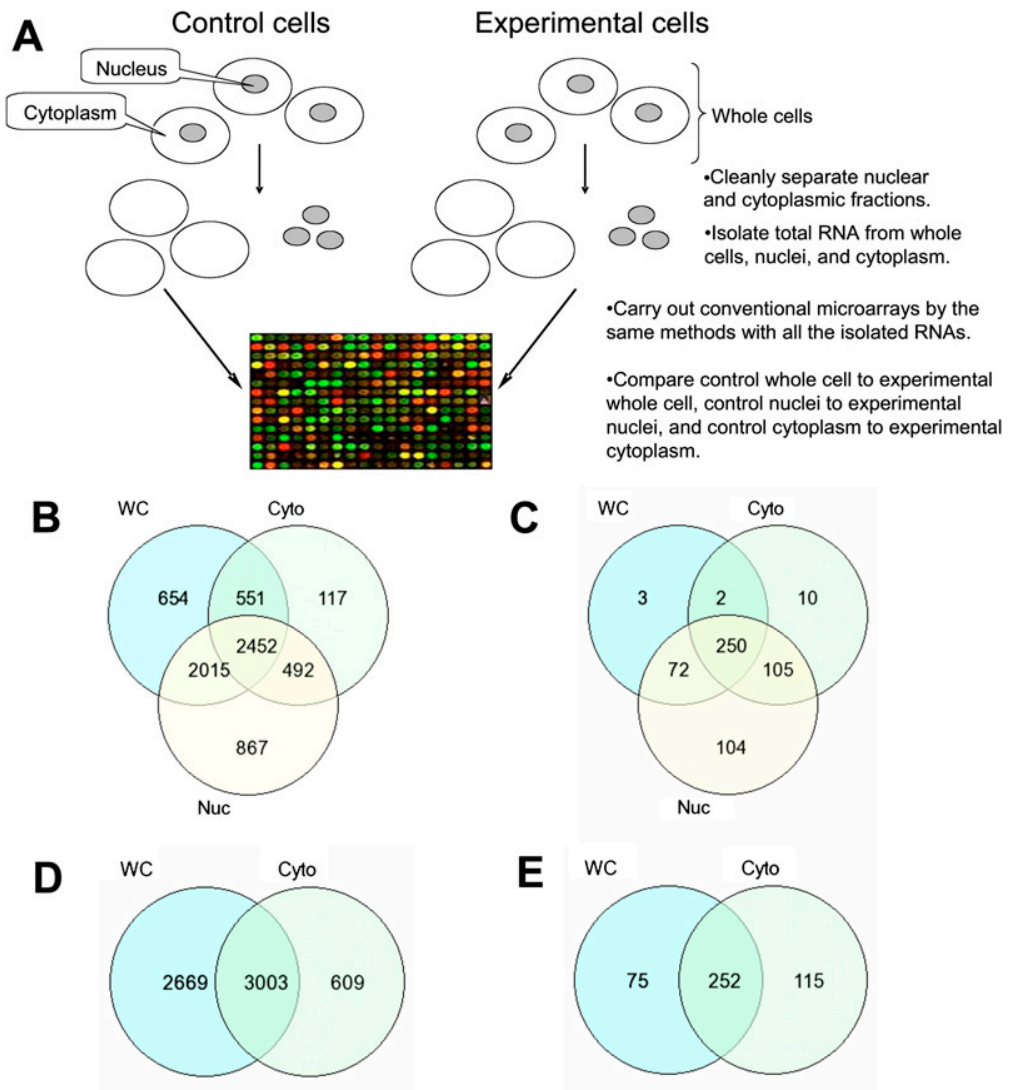

Using whole cell RNA isolation: $\cdot 609$ steady-state mRNAs missed
$\cdot 2669$ false-positives

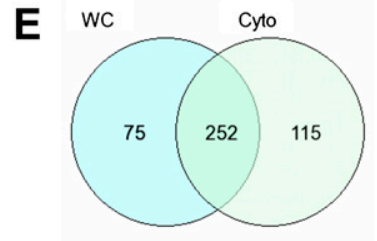

Using whole cell RNA isolation: - 115 steady-state mRNAs missed
.75 false-positives

FIGURE 2. Microarray experimental design and results. (A) The two sets of microarray experiments were carried out in quadruplicate (four biological replicates) with equal amounts $(2 \mu \mathrm{g})$ of total RNA from the control whole cell, nuclear, and cytoplasmic fractions and the corresponding experimental whole cell, nuclear, and cytoplasmic fractions from the mouse Hepa-1c1c7 and human BxPC3 cells. Microarray analyses were carried out by identifying significantly changed genes $(P$-value $\leq 0.05)$. The numbers of unique differentially expressed genes generated by the different cellular compartments are displayed in Venn diagrams (22) for the mouse Hepa-1c1c7 $(B, D)$ and human BxPC3 pancreatic cancer $(C, E)$ cells. $(B, C)$ Comparison of whole cell, cytoplasmic, and nuclear RNA levels. $(D, E)$ Comparison of whole cell and cytoplasmic RNA levels. (WC) Whole cell, (Nuc) nucleus, (Cyto) cytoplasm.

nuclear or cytoplasmic fractions, but not both. The heat maps illustrate how the whole cell RNA population was altered when changes occurred only in the nuclear or cytoplasmic RNA levels and further show that whole cell RNA levels changed without the ability to distinguish where those changes occurred (cytoplasm or nucleus).

The number of unique differentially expressed genes for the different cellular compartments are displayed in Venn diagrams (Fig. 2B-E; Pirooznia et al. 2007), from which some conclusions can be drawn. First, differentially expressed genes were identified in the cytoplasmic fractions that would have been missed using whole cell RNA (Fig. 2D,E, 609 and 115 genes in the Hepa-1c1c7 and BxPC3 cells, respectively). The missed cytoplasmic genes with the greatest relative fold changes are shown in Table 1, and the complete lists of missed genes are shown in Supplemental
Tables S3-S6 $(P$-value $\leq 0.05$, false discovery rate $\leq 0.1$ ) (Wolfinger et al. 2001). Possible hypotheses to explain the missed genes is that: (1) the differential expression of nuclear RNA is so highly variable as to swamp out any significant effects of the cytoplasmic RNA that in turn make the whole cell RNA statistically nonsignificant (Supplemental Table S7, see "Nuclear dominance"); or (2) the relative changes in RNA levels for both the nucleus and cytoplasm were significant in opposite directions to render the whole cell results statistically nonsignificant (Supplemental Table S7, see "Nuclear/cytoplasmic complement"). Supplemental Table S7 summarizes the findings for the missed genes, in which those genes at $P$-value $\leq 0.05$, for example, are $\sim 41 \%$ and $12 \%$ of the Hepa-1c1c7 and BxPC3 cells, respectively—supporting the above hypotheses. The remaining missed genes in Supplemental Table S7 are listed under "Technical variability" and may represent genes of lower intensities such that small changes in RNA levels generated disproportionately large effects. The variable missed genes are listed in Supplemental Tables S3-S6.

Second, the contribution by the nuclear compartment was not negligible; 2669 and 75 of the genes in the Hepa$1 \mathrm{clc} 7$ and BxPC 3 cells, respectively, that were significantly expressed in whole cells were not found in the cytoplasm. These genes are defined as false positives. The false positive genes with the greatest relative fold changes are shown in Table 2, and the complete list of false positive genes is given in Supplemental Tables S8-S11. A possible hypothesis to explain the false positive genes is that the differential expression of nuclear RNA is so great and highly statistically significant as to swamp out any variable effects of the cytoplasmic RNA; for the most part, the false positive results supported the above hypothesis. For example, $\sim 76 \%$ and $55 \%$ of the genes at $P$-value $\leq 0.05$ for the Hepa-1c1c7 and BxPC3 cells, respectively, were dominated by the nuclear component (Supplemental Table S7). The false positive genes that did not support the hypothesis are listed in Supplemental Table S7 under "Technical variability," and again, probably represent genes of lower intensities such that small changes in RNA levels caused disproportionately large effects. The list of variable false positive genes is included in Supplemental Tables S8-S11. 
TABLE 1. Missed genes: Top differentially expressed genes detected in the cytoplasm but not in the whole cell $(P$-value $=0.05)$

\begin{tabular}{|c|c|c|c|c|}
\hline \multirow[b]{2}{*}{ Cell type } & \multirow[b]{2}{*}{ Gene ID } & \multirow[b]{2}{*}{ Gene symbol } & \multicolumn{2}{|c|}{ Relative fold change } \\
\hline & & & Whole cell & Cytoplasm \\
\hline \multicolumn{5}{|c|}{ Mouse Hepa-1c1c7 cells TCDD-treated/vehicle-treated } \\
\hline & NM_146738 & Olfr497 & -1.03 & 2.63 \\
\hline & NM_026337 & Sltm & 1.22 & 2.00 \\
\hline & NM_026573 & Upf3b & 1.10 & 1.79 \\
\hline & NM_138741 & Sdpr & 1.13 & 1.75 \\
\hline & NM_001033463 & Tatdn2 & 1.11 & 1.71 \\
\hline & NM_027696 & Mier1 & 1.14 & 1.68 \\
\hline & NM_199448 & Fez2 & -1.05 & 1.68 \\
\hline & NM_026201 & Ccar1 & 1.20 & 1.65 \\
\hline & NM_181542 & Slfn10 & 1.06 & 1.63 \\
\hline & NM_026095 & Snrpd3 & 1.19 & 1.62 \\
\hline & XM_888341 & Trio & -1.19 & -1.79 \\
\hline & NAP036221-1 & NAP036221-1 & 1.07 & -1.80 \\
\hline & XM_886913 & D230004J03Rik & 1.10 & -1.81 \\
\hline & NM_146182 & Klc3 & -1.06 & -1.84 \\
\hline & AK017529 & Sf3b3 & 1.05 & -1.84 \\
\hline & АК043743 & АК043743 & -1.17 & -1.84 \\
\hline & AK148746 & AK148746 & 1.12 & -1.91 \\
\hline & AK049456 & Wdfy3 & -1.02 & -2.05 \\
\hline & BC010335 & BC010335 & -1.12 & -2.34 \\
\hline & NM_010397 & $\mathrm{H} 2-\mathrm{T} 22$ & -1.24 & -2.43 \\
\hline \multicolumn{5}{|c|}{ Human BxPC3 cells Sham vector/Smad4-positive } \\
\hline & NM_000927 & ABCB1 & 1.12 & 2.63 \\
\hline & NM_018566 & YOD1 & 1.01 & 1.73 \\
\hline & A_32_P112531 & A_32_P112531 & 1.05 & 1.62 \\
\hline & NM_Ē024511 & C4orf15 & 1.09 & 1.60 \\
\hline & ВС045098 & ВС045098 & -1.01 & 1.56 \\
\hline & NM_032152 & PRAM1 & 1.04 & 1.53 \\
\hline & NM_181711 & GRASP & 1.07 & 1.51 \\
\hline & ENST00000354349 & ENST00000354349 & -1.02 & -1.56 \\
\hline & NM_147198 & WFDC9 & -1.01 & -1.70 \\
\hline & NM_138805 & FAM3D & -1.12 & -1.92 \\
\hline
\end{tabular}

volvement of the TGF- $\beta$ signaling pathway, which would be expected in two cell types that differ only in the expression of the SMAD4 gene (Yasutome et al. 2005). The findings showed that two genes in the TGF- $\beta$ signaling pathway, BMP4 (NM_001202) and LEF1 (NM_016269) (Supplemental Tables S5, S6), were up-regulated by SMAD4 in BxPC3 cells. The increased expression of both genes would have been missed if whole cell RNA had been examined. This new information may explain why expression of wild-type SMAD4 in BxPC3 cells causes only a transient attenuation of their capacity to proliferate in nude mice, since LEF1 interacts with SMAD4 to up-regulate MYC expression in a TGF- $\beta$-independent manner (Lim and Hoffmann 2006), while BMP4 exerts paracrine effects that may promote tumor growth (Massague 2008), and BMPR-IA and BMPR-II expression is increased in pancreatic cancer (Kleeff et al. 1999). These observations suggest that SMAD4-mediated BMP4 up-regulation may promote cancer growth in vivo both by cell autonomous and by autocrine and paracrine mechanisms, allowing SMAD4 growth inhibitory actions to be circumvented. Redundant perturbations within specific signaling cascades and the capacity of pancreatic cancer cells to exhibit perturbations in a dozen key pathways (Jones et al. 2008) serve to underscore the

The gene lists for the whole cell, nuclear, and cytoplasmic fractions were annotated with functional assignments and sorted into gene-related categories using Expression Analysis Systematic Explorer (EASE) (Table 3; Hosack et al. 2003), and included the three branches of the Gene Ontology (GO) database (Ashburner et al. 2000) and GenMAPP (Salomonis et al. 2007). There was no overlap between the whole cell and cytoplasmic fractions for the Hepa-1c1c7 cells for any of the top 10 GO categories, and only half of the whole cell and cytoplasmic categories overlapped for the GenMAPP categories. In contrast, there was considerable overlap between the whole cell and nuclear fractions. Similarly for the BxPC3 cells, there was relatively little overlap between the whole cell and cytoplasmic compartments, but a large degree of overlap between the cytoplasmic and nuclear compartments.

To highlight the potential power of using cytoplasmic RNA, only the cytoplasmic RNA fraction of BxPC3 cells from the GenMAPP analysis (Table 3) revealed the in- difficulties in designing effective therapies for this deadly cancer. In the case of TCDD exposure to mouse Hepa1c1c7 cells, two missed genes include Sltm and Ccar1 (Table 1; Supplemental Tables S3, S4), which play recently discovered critical roles in transcriptional regulation (Chan et al. 2007; Kim et al. 2008). Our findings support the hypothesis that whole cell preparation of RNA does not accurately represent steady-state mRNA levels because of the nuclear RNA contribution and that the cytoplasmic RNA fraction produces a more precise determination of the mRNA steadystate profile and impact on possible cellular processes.

\section{DISCUSSION}

The implications of our work are far reaching in that few, if any, of the thousands of high-throughput microarray gene expression studies undertaken to determine differential mRNA levels have taken into consideration the issue of hybridization by nuclear RNA. Furthermore, our findings can 
TABLE 2. False positives: Top differentially expressed genes detected in the whole cell but not in the cytoplasm $(P$-value $=0.05)$

\begin{tabular}{|c|c|c|c|c|}
\hline \multirow[b]{2}{*}{ Cell type } & \multirow[b]{2}{*}{ Gene ID } & \multirow[b]{2}{*}{ Gene symbol } & \multicolumn{2}{|c|}{ Relative fold change } \\
\hline & & & Whole cell & Cytoplasm \\
\hline \multicolumn{5}{|c|}{ Mouse Hepa-1c1c7 cells TCDD-treated/vehicle-treated } \\
\hline & AK013994 & AK013994 & 4.84 & -1.15 \\
\hline & AK147659 & Bc19 & 4.60 & 1.16 \\
\hline & AK089821 & F830028O17Rik & 4.57 & 1.09 \\
\hline & XM_923365 & D430007A19Rik & 4.01 & 1.20 \\
\hline & BE573237 & BE573237 & 3.94 & 1.10 \\
\hline & TC1650301 & TC1650301 & 3.90 & 1.02 \\
\hline & BU511373 & $\mathrm{H} 1 \mathrm{fx}$ & 3.83 & 1.06 \\
\hline & AK013239 & AK013239 & 3.74 & 1.19 \\
\hline & ВC071254 & ВC071254 & 3.56 & -1.18 \\
\hline & AK079540 & Riok1 & 3.52 & 1.07 \\
\hline & ВС009101 & Ankrd32 & -2.63 & -1.17 \\
\hline & NM_145954 & Aldh16a1 & -2.66 & -1.13 \\
\hline & NM_029092 & Rg9mtd1 & -2.68 & -1.18 \\
\hline & NM_145484 & Zfp758 & -2.77 & -1.20 \\
\hline & AK029960 & Cep290 & -2.88 & -1.06 \\
\hline & XM_984400 & 1700123A16Rik & -3.01 & -1.06 \\
\hline & NM_176962 & 6330416L07Rik & -3.05 & -1.16 \\
\hline & AK033431 & Egfr & -3.11 & -1.19 \\
\hline & NM_009558 & Zfp51 & -3.33 & -1.13 \\
\hline & AK031844 & AK031844 & -3.45 & 1.02 \\
\hline \multicolumn{5}{|c|}{ Human BxPC3 cells Sham vector/Smad4-positive } \\
\hline & NM_000930 & PLAT & 1.66 & 1.04 \\
\hline & NM_006732 & FOSB & 1.51 & 1.10 \\
\hline & NM_178230 & PP1AL4 & 1.29 & -1.13 \\
\hline & A_24_P418106 & A_24_P418106 & 1.28 & -1.11 \\
\hline & ENST00000306716 & ENST00000306716 & 1.28 & -1.12 \\
\hline & ENST00000343756 & ENST00000343756 & 1.28 & -1.11 \\
\hline & ENST00000312958 & ENST00000312958 & 1.27 & -1.11 \\
\hline & ENST00000324656 & ENST00000324656 & 1.27 & -1.11 \\
\hline & A_24_P58727 & A_24_P58727 & 1.26 & -1.13 \\
\hline & ENST00000240820 & ENST00000240820 & 1.26 & -1.11 \\
\hline & NM_020238 & INCENP & -1.44 & 1.09 \\
\hline & NM_174936 & PCSK9 & -1.44 & -1.07 \\
\hline & NM_015541 & LRIG1 & -1.56 & -1.07 \\
\hline & NM_015088 & TNRC6B & -1.59 & -1.13 \\
\hline & NM_015973 & GAL & -1.61 & -1.07 \\
\hline & NM_001850 & COL8A1 & -1.68 & -1.07 \\
\hline & NM_001955 & EDN1 & -1.68 & 1.10 \\
\hline & NM_017510 & TMED9 & -1.69 & 1.11 \\
\hline & NM_004385 & VCAN & -1.74 & -1.04 \\
\hline & NM_006902 & PRRX1 & -3.96 & -1.03 \\
\hline
\end{tabular}

component is not negligible are: (1) all cytoplasmic poly $(\mathrm{A})^{+}$RNA, to varying degrees, is represented in the corresponding nuclear RNA pool (Sippel et al. 1977), and any labeled nuclear target of a different proportion to that of the labeled cytoplasmic target will alter signal intensity ratios; and (2) because of the relatively large amount of nonspecific nuclear RNA in the cell (Supplemental Tables S12, S13), via the law-of-mass action, the nuclear RNA will swamp out the rarer cytoplasmic targets (Zhang et al. 2005). That is, the overall mRNA complexity is vastly reduced when the nuclear RNA fraction is removed; and reducing the complexity of whole cell RNA greatly enriches the rarer transcript population, allowing the detection of 10-fold more differentially expressed genes via microarrays (Sakai et al. 2000).

Recent work has shown that genomic transcription is much more complex and widespread than previously believed (Katayama et al. 2005; Kapranov et al. 2007; He et al. 2008; Preker et al. 2008; Seila et al. 2008), which includes evidence that nuclear RNA has an effect on gene expression profiling. In one study (Cheng et al. 2005), tiling arrays with 5-base-pair-spaced resolution were used to examine transcribed sequences from 10 chromosomes in eight different human cell lines. The overall amounts of $\operatorname{poly}(\mathrm{A})^{+}$RNA sequences detected exclusively in the nucleus versus cytoplasm were $9.7 \%$ and $3.1 \%$, respectively, and $25 \%$ of the nuclear poly $(\mathrm{A})^{+}$RNA was associated with well-annotated exonic regions. Thus, there is a relatively large population of nuclear RNA that can contribute to the overall signal in a typical microarray experiment. In another study (Barthelson et al. 2007), a direct comparison of the nuclear and

be applied to other high-throughput approaches, including deep sequencing. The prevailing notion that nuclear RNA is a minor component is based primarily on early $\mathrm{R}_{\mathrm{o}} \mathrm{t}$ solution hybridization studies, in which it was shown that the frequency and abundance of polysomal mRNA to nuclear RNA is $\sim 100$-fold (Sippel et al. 1977). However, those studies also showed that all polysomal mRNA species are represented in the corresponding nuclear RNA, and that nuclear RNA is $\sim 5-10$ times more complex than polysomal mRNA. Thus, the primary reasons that the nuclear RNA cytoplasmic RNA fractions on microarrays from unperturbed human hepatoma HepG2 cells revealed that the nuclear and cytoplasmic RNA profiles were similar but with notable exceptions. Nuclear RNA samples were enriched with transcripts encoding proteins associated with a set of specific nuclear functions, which were similar to the observations we had reported (Schwanekamp et al. 2006), while cytoplasmic RNA samples were enriched in transcripts encoding proteins with a different set of specific nuclear functions and the ubiquitin cycle. 
The full transcriptional diversity of a cell requires an understanding of both nuclear and cytoplasmic transcripts; however, the exclusion of nuclear RNA may not only provide a more accurate measure of steady-state mRNA levels, but also may (1) produce more reproducible results by omitting certain variably expressed nuclear RNA species; (2) uncover heretofore missed genes; and (3) greatly reduce the number of false positives. In conclusion, we are not asserting that all prior microarray studies are wrong or misleading, but that they represent whole cell RNA levels, not steady-state mRNA levels. Thus, to obtain a truer picture of steady-state mRNA levels, when feasible, cytoplasmic RNA alone should be examined.

\section{MATERIALS AND METHODS}

\section{Cell cultures}

Mouse hepatoma Hepa-1c1c7 cells were grown in $\alpha$-minimal essential medium (Invitrogen) supplemented with 5\% fetal bovine serum, $100 \mu \mathrm{g} / \mathrm{mL}$ penicillin, and $100 \mu \mathrm{g} / \mathrm{mL}$ streptomycin. Treated Hepa-1c1c7 cells were exposed to $10 \mathrm{nM}$ 2,3,7,8-tetrachlorodibenzop-dioxin (TCDD) for $2 \mathrm{~h}$ at $80 \%$ confluence, while control cells were exposed to the vehicle (dimethyl sulfoxide) only. BxPC3 cells were grown in RPMI-1640, supplemented with 10\% FBS, 100 units/mL penicillin, $100 \mu \mathrm{g} / \mathrm{mL}$ streptomycin, and $5 \%$ fungizone (Yasutome et al. 2005). Cells were maintained in monolayer cultures at $37^{\circ} \mathrm{C}$ in humidified air with $5 \% \mathrm{CO}_{2}$, and cell numbers were determined by counting the cells with a hemocytometer.

\section{Nuclear and cytoplasmic fractionation}

The nuclear and cytoplasmic fractions were isolated as described (Yasutome et al. 2005). The Hepa-1c1c7 and BxPC3 cells were incubated for $30 \mathrm{~min}$ at $4^{\circ} \mathrm{C}$ in hypotonic buffer $(20 \mathrm{mM}$ HEPES at $\mathrm{pH} 7.6,20 \%$ glycerol, $10 \mathrm{mM} \mathrm{NaCl}, 1.5 \mathrm{mM} \mathrm{MgCl}_{2}$, $0.2 \mathrm{mM}$ EDTA, $0.1 \%$ Triton X-100, $25 \mathrm{mM} \mathrm{NaF}, 25 \mathrm{mM}$ $\beta$-glycerophosphate, $1 \mathrm{mM}$ PMSF, $1 \mathrm{mM}$ sodium orthovanadate, $1 \mathrm{mM}$ dithiothreitol, $1 \mu \mathrm{g} / \mathrm{mL}$ Leupeptin, and $1 \mu \mathrm{g} / \mathrm{mL}$ Aprotinin). Following centrifugation at $1700 \mathrm{rpm}$ for $5 \mathrm{~min}$, supernatants were used for the cytoplasmic fraction. The pelleted nuclei were washed with PBS and incubated for $10 \mathrm{~min}$ at $4^{\circ} \mathrm{C}$ in nuclear extraction buffer (hypotonic buffer containing $500 \mathrm{mM} \mathrm{NaCl}$ ) and cleared by centrifugation.

\section{RNA purification}

Cells and cellular fractions were homogenized in $1 \mathrm{~mL}$ of TRIzol Reagent (Invitrogen), and RNA was purified and isolated using RNeasy Kits (Qiagen). RNA purity and quantity was determined using a NanoDrop spectrophotometer (ND-1000; NanoDrop Technologies), and RNA integrity was assessed by Agilent biosizing gel separation (Agilent Technologies) (Wang et al. 2006).

\section{Microarrays}

cRNA amplification and fluorescence labeling was performed using the Agilent Low RNA Input Fluorescent Linear Amplification Kit (Agilent Technologies) (Schwanekamp et al. 2006). The labeled target was combined and allowed to hybridize to probes on the Agilent $4 \times 44 \mathrm{~K}$ whole mouse genome or whole human genome oligo microarray slides in an oven rotator for $18 \mathrm{~h}$ at $60^{\circ} \mathrm{C}$. The arrays were scanned using an Agilent Microarray Scanner laser based detection system. All normalizations were performed using default settings in the Feature Extraction.

\section{Microarray data analysis}

The data analysis was carried out by performing loess normalization (Smyth and Speed 2003) without background correction to pre-process the image files from the Agilent Feature Extraction software (Zahurak et al. 2007) and an intensity-based, modified $t$-test (Sartor et al. 2006) to characterize the significance level of each feature using limma R packages from Bioconductor (Smyth 2005). Cluster analysis was performed using the Bayesian infinite mixture models (Medvedovic and Sivaganesan 2002) as implemented in the GIMM software (http://eh3.uc.edu/gimm). Significantly differentially expressed genes were annotated with functional assignments to help determine which gene categories were enriched with differentially expressed genes using EASE, and the gene categories used were GenMAPP and the three branches of the and Gene Ontology (GO) database: biological process, molecular function, and cellular component (Ashburner et al. 2000). Venn diagrams of the statistical results were constructed using the GeneVenn software package (Pirooznia et al. 2007).

\section{Quantitative polymerase chain reaction}

QPCR analysis using SYBR green and designed primers (Supplemental Table S1) was carried out to verify the microarray results (Schwanekamp et al. 2006). Primers were designed that corresponded near or to the region of the RNA transcript that matched the 70-mer oligonucleotide sequence printed on the microarray. Approximately $2 \mu \mathrm{g}$ of total RNA (the same RNA used for the microarrays) was used as template for cDNA synthesis in the QPCR reactions. The QPCR reactions were preformed on a DNA Engine Opticon Monitor System using software version 3.1 (Bio-Rad) set at 35-40 cycles. Assays using agarose gel electrophoresis showed that each PCR produced a single band of the predicted size. Assays to determine DNA contamination were carried out by omitting reverse transcriptase from the reactions.

\section{Western blotting}

Antibodies to mouse and human PARP-1 (Santa Cruz Biotechnology), $\alpha$-TUBULIN (Sigma), mouse GRB-2 (BD Biosciences), and human VINCULIN (AnaSpec) were used in the immunoblotting procedures. As previously described (Yasutome et al. 2005), exponentially growing Hepa-1c1c7 and BxPC3 cells were rinsed with phosphate buffered saline at $4^{\circ} \mathrm{C}$, and lysed in buffer containing 1\% NP40, $20 \mathrm{mM}$ Tris ( $\mathrm{pH} 8.0$ ), $150 \mathrm{mM} \mathrm{NaCl}, 1 \mathrm{mM}$ EDTA, $1 \mathrm{mM}$ EGTA, $2.5 \mathrm{mM}$ sodium phosphate, $1 \mathrm{mM}$ $\beta$-glycerophosphate, $1 \mathrm{mM}$ sodium vanadate, $1 \mathrm{~g} / \mathrm{mL}$ leupeptin, and $1 \mathrm{mM}$ phenylmethylsulfonyl fluoride. Proteins were resolved by SDS-PAGE and electrotransferred to Immobilon-P membranes for 30-90 min. After blocking with 5\% milk, the membranes were incubated with the indicated antibodies, rinsed, and incubated with a secondary horseradish peroxidase-conjugated antibody. Bound antibodies were enhanced by chemiluminescence. 


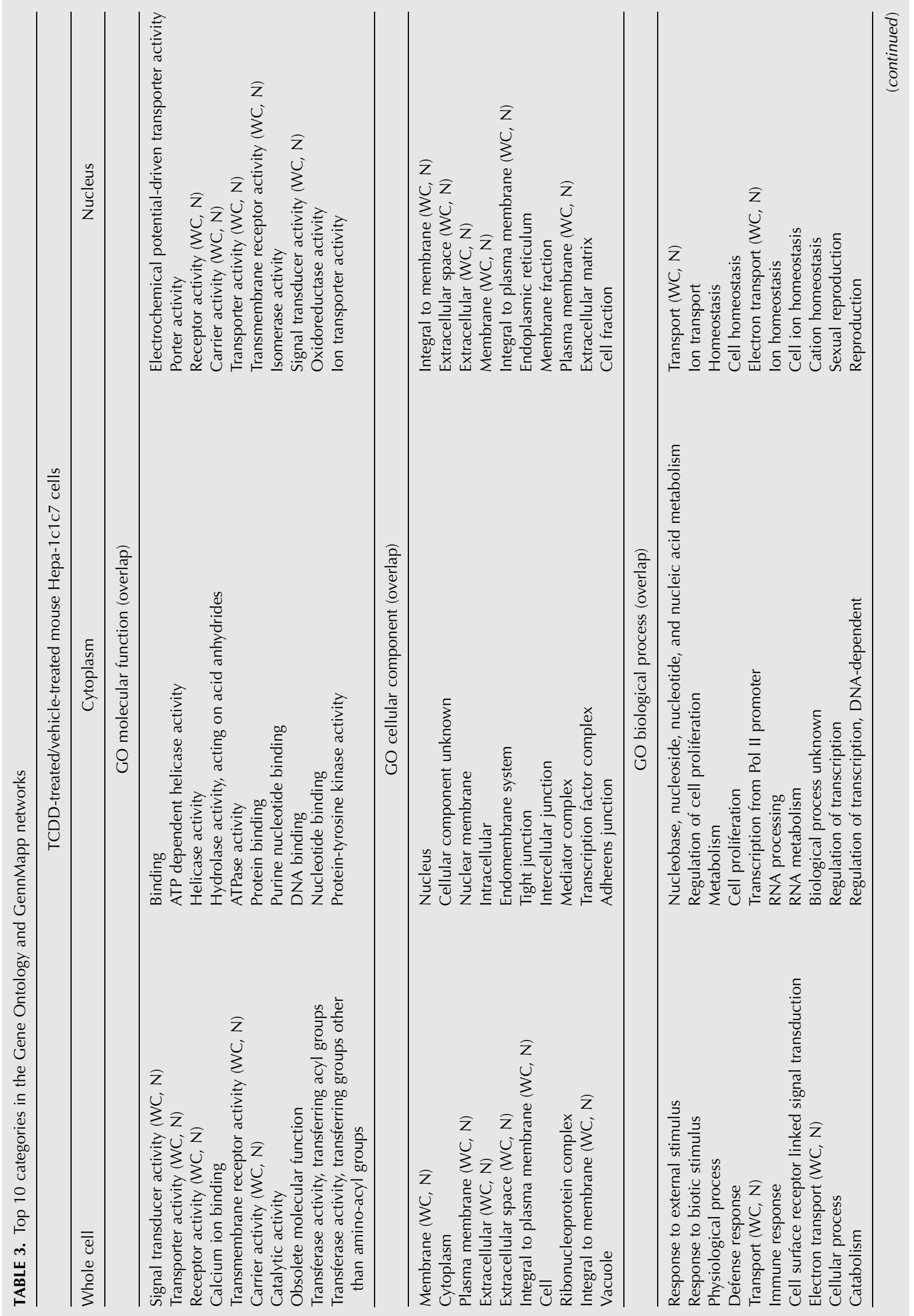




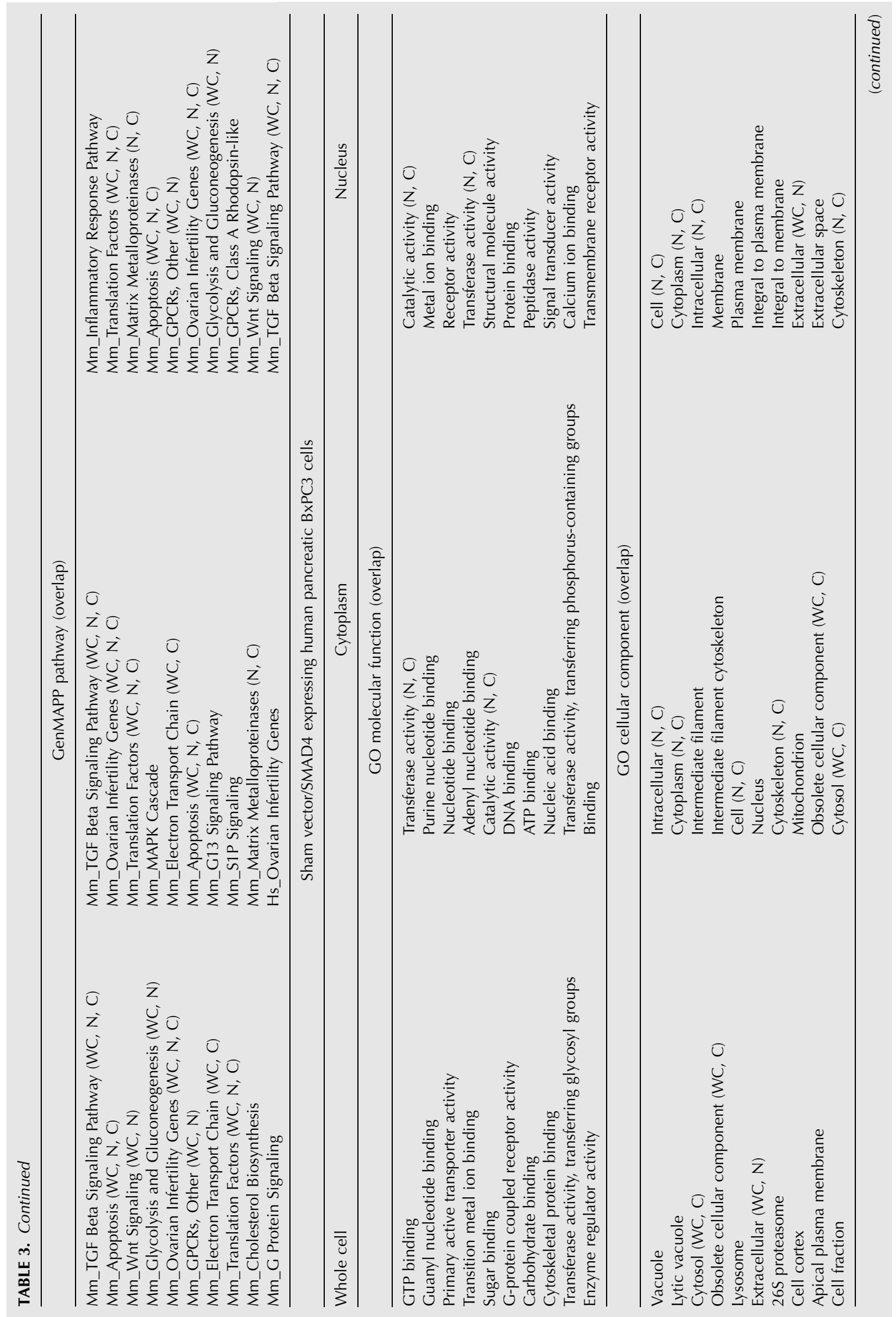




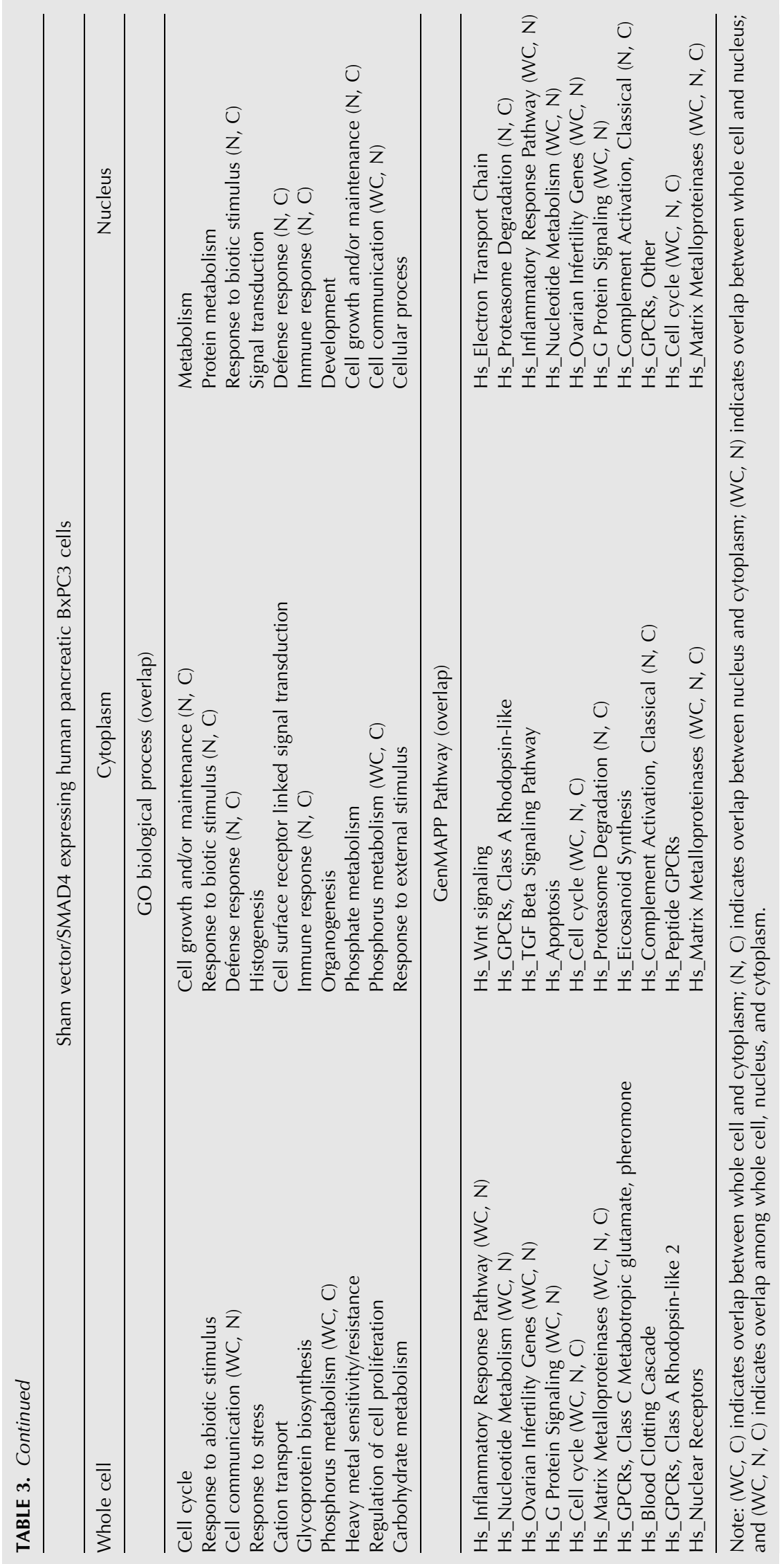




\section{SUPPLEMENTAL DATA}

Supplemental material can be found at http://www.rnajournal.org.

\section{ACKNOWLEDGMENTS}

We thank Drs. Chuck Cole, Larry Meyers, Yolanda Sanchez, and Michael Whitfield of the Dartmouth Medical School and Norris Cotton Cancer Center for their critical reading of the manuscript; and we thank the reviewers for their thoughtful comments. This work was supported by NIH/NIEHS grant R21ES013827 to C.R.T.

Received April 5, 2009; accepted July 22, 2009.

\section{REFERENCES}

Ashburner M, Ball CA, Blake JA, Botstein D, Butler H, Cherry JM, Davis AP, Dolinski K, Dwight SS, Eppig JT, et al. 2000. Gene ontology: Tool for the unification of biology. The Gene Ontology Consortium. Nat Genet 25: 25-29.

Barthelson RA, Lambert GM, Vanier C, Lynch RM, Galbraith DW. 2007. Comparison of the contributions of the nuclear and cytoplasmic compartments to global gene expression in human cells. BMC Genomics 8: 340. doi: 10.1186/1471-2164-8340.

Birnstiel MLA, Busslinger M, Strub K. 1985. Transcription termination and $3^{\prime}$ processing: The end is in site! Cell 41: 349359.

Brown PO, Botstein D. 1999. Exploring the new world of the genome with DNA microarrays. Nat Genet 21: 33-37.

Chan CW, Lee YB, Uney J, Flynn A, Tobias JH, Norman M. 2007. A novel member of the SAF (scaffold attachment factor)-box protein family inhibits gene expression and induces apoptosis. Biochem J 407: 355-362.

Cheadle C, Fan J, Cho-Chung YS, Werner T, Ray J, Do L, Gorospe M, Becker KG. 2005. Stability regulation of mRNA and the control of gene expression. Ann N Y Acad Sci 1058: 196-204.

Cheng J, Kapranov P, Drenkow J, Dike S, Brubaker S, Patel S, Long J, Stern D, Tammana H, Helt G, et al. 2005. Transcriptional maps of 10 human chromosomes at 5-nucleotide resolution. Science 308: $1149-1154$.

Dominski Z, Marzluff WF. 2007. Formation of the $3^{\prime}$ end of histone mRNA: Getting closer to the end. Gene 396: 373-390.

Garcia-Martinez J, Aranda A, Perez-Ortin JE. 2004. Genomic run-on evaluates transcription rates for all yeast genes and identifies gene regulatory mechanisms. Mol Cell 15: 303-313.

Guo J, Sartor M, Karyala S, Medvedovic M, Kann S, Puga A, Ryan P, Tomlinson CR. 2004. Expression of genes in the TGF- $\beta$ signaling pathway is significantly deregulated in smooth muscle cells from aorta of aryl hydrocarbon receptor knockout mice. Toxicol Appl Pharmacol 194: 79-89.

Hankinson O, Brooks BA, Weir-Brown KI, Hoffman EC, Johnson BS, Nanthur J, Reyes H, Watson AJ. 1991. Genetic and molecular analysis of the Ah receptor and of Cyplal gene expression. Biochimie 73: 6166.

He Y, Vogelstein B, Velculescu VE, Papadopoulos N, Kinzler KW. 2008. The antisense transcriptomes of human cells. Science 322: 1855-1857.

Hosack DA, Dennis G Jr, Sherman BT, Lane HC, Lempicki RA. 2003. Identifying biological themes within lists of genes with EASE. Genome Biol 4: R70. doi: 10.1186/gb-2003-4-10-r70.

Jackson DA, Pombo A, Iborra F. 2000. The balance sheet for transcription: An analysis of nuclear RNA metabolism in mammalian cells. FASEB J 14: 242-254.
Jones S, Zhang X, Parsons DW, Lin JC-H, Leary RJ, Angenendt P, Mankoo P, Carter H, Kamiyama H, Jimeno A, et al. 2008. Core signaling pathways in human pancreatic cancers revealed by global genomic analyses. Science 321: 1801-1806.

Kapranov P, Cheng J, Dike S, Nix DA, Duttagupta R, Willingham AT, Stadler PF, Hertel J, Hackermuller J, Hofacker IL, et al. 2007. RNA maps reveal new RNA classes and a possible function for pervasive transcription. Science 316: 1484-1488.

Katayama S, Tomaru Y, Kasukawa T, Waki K, Nakanishi M, Nakamura M, Nishida H, Yap CC, Suzuki M, Kawai J, et al. 2005. Antisense transcription in the mammalian transcriptome. Science 309: 1564-1566.

Kim JH, Yang CK, Heo K, Roeder RG, An W, Stallcup MR. 2008. CCAR1, a key regulator of mediator complex recruitment to nuclear receptor transcription complexes. Mol Cell 31: 510519.

Kleeff J, Ishiwata T, Maruyama H, Friess H, Truong P, Buchler MW, Falb D, Korc M. 1999. The TGF- $\beta$ signaling inhibitor Smad7 enhances tumorigenicity in pancreatic cancer. Oncogene 18: 53635372.

Lim SK, Hoffmann FM. 2006. Smad4 cooperates with lymphoid enhancer-binding factor $1 / \mathrm{T}$ cell-specific factor to increase c-myc expression in the absence of TGF- $\beta$ signaling. Proc Natl Acad Sci 103: $18580-18585$.

Massague J. 2008. TGF $\beta$ in cancer. Cell 134: 215-230.

Medvedovic M, Sivaganesan S. 2002. Bayesian infinite mixture model based clustering of gene expression profiles. Bioinformatics 18: 1194-1206.

Pirooznia M, Nagarajan V, Deng Y. 2007. GeneVenn-a web application for comparing gene lists using Venn diagrams. Bioinformation 1: 420-422.

Preker P, Nielsen J, Kammler S, Lykke-Andersen S, Christensen MS, Mapendano CK, Schierup MH, Jensen TH. 2008. RNA exosome depletion reveals transcription upstream of active human promoters. Science 322: 1851-1854.

Sakai K, Higuchi H, Matsubara K, Kato K. 2000. Microarray hybridization with fractionated cDNA: Enhanced identification of differentially expressed genes. Anal Biochem 287: 32-37.

Salomonis N, Hanspers K, Zambon AC, Vranizan K, Lawlor SC, Dahlquist KD, Doniger SW, Stuart J, Conklin BR, Pico AR. 2007. GenMAPP 2: New features and resources for pathway analysis. BMC Bioinformatics 8: 217. doi: 10.1186/1471-2105-8217.

Sartor MA, Tomlinson CR, Wesselkamper SC, Sivaganesan S, Leikauf GD, Medvedovic M. 2006. Intensity-based hierarchical Bayes method improves testing for differentially expressed genes in microarray experiments. BMC Bioinformatics 7: 538. doi: 10.1186/ 1471-2105-7-538.

Schwanekamp JA, Sartor MA, Karyala S, Halbleib D, Medvedovic M, Tomlinson CR. 2006. Genome-wide analyses show that nuclear and cytoplasmic RNA levels are differentially affected by dioxin. Biochim Biophys Acta 1759: 388-402.

Seila AC, Calabrese JM, Levine SS, Yeo GW, Rahl PB, Flynn RA, Young RA, Sharp PA. 2008. Divergent transcription from active promoters. Science 322: 1849-1851.

Sippel AE, Hynes N, Groner B, Schutz G. 1977. Frequency distribution of messenger sequences within polysomal mRNA and nuclear RNA from rat liver. Eur J Biochem 77: 141-151.

Smyth GK. 2005. Limma: Linear models for microarray data. In Bioinformatics and computational biology solutions using $R$ and bioconductor (eds. R Gentleman et al.), pp 397-420. Springer, New York.

Smyth GK, Speed T. 2003. Normalization of cDNA microarray data. Methods 31: 265-273.

Tan MH, Nowak NJ, Loor R, Ochi H, Sandberg AA, Lopez C, Pickren JW, Berjian R, Douglass HO Jr, Chu TM. 1986. Characterization of a new primary human pancreatic tumor line. Cancer Invest 4: 15-23. 
Van Ness J, Hahn WE. 1980. Sequence complexity of cDNA transcribed from a diverse mRNA population. Nucleic Acids Res 8: $4259-4270$.

Wang Y, Zhu W, Levy DE. 2006. Nuclear and cytoplasmic mRNA quantification by SYBR green based real-time RT-PCR. Methods 39: 356-362.

Wolfinger RD, Gibson G, Wolfinger ED, Bennett L, Hamadeh H, Bushel P, Afshari C, Paules RS. 2001. Assessing gene significance from cDNA microarray expression data via mixed models. $J$ Comput Biol 8: 625-637.
Yasutome M, Gunn J, Korc M. 2005. Restoration of Smad4 in BxPC3 pancreatic cancer cells attenuates proliferation without altering angiogenesis. Clin Exp Metastasis 22: 461-473.

Zahurak M, Parmigiani G, Yu W, Scharpf RB, Berman D, Schaeffer E, Shabbeer S, Cope L. 2007. Pre-processing Agilent microarray data. BMC Bioinformatics 8: 142. doi: 10.1186/14712105-8-142.

Zhang Y, Hammer DA, Graves DJ. 2005. Competitive hybridization kinetics reveals unexpected behavior patterns. Biophys $J$ 89: 2950-2959. 

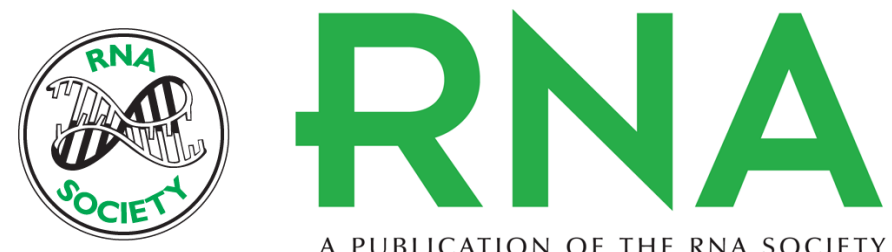

A PUBLICATION OF THE RNA SOCIETY

\section{Microarray analysis of cytoplasmic versus whole cell RNA reveals a considerable number of missed and false positive mRNAs}

Heidi W. Trask, Richard Cowper-Sal-lari, Maureen A. Sartor, et al.

RNA 2009 15: 1917-1928 originally published online August 24, 2009

Access the most recent version at doi:10.1261/rna.1677409

\section{Supplemental http://rnajournal.cshlp.org/content/suppl/2009/08/07/rna.1677409.DC1 \\ Material}

References This article cites 38 articles, 9 of which can be accessed free at:

http://rnajournal.cshlp.org/content/15/10/1917.full.html\#ref-list-1

\section{License}

Email Alerting Receive free email alerts when new articles cite this article - sign up in the box at the Service top right corner of the article or click here.

\section{III!"II Providing Precise Solutions tor your research.}

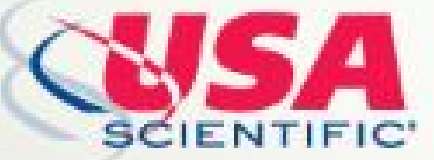

To subscribe to $R N A$ go to:

http://rnajournal.cshlp.org/subscriptions 